\author{
精巣腫瘍156例の臨床統計 \\ 大阪大学医学部泌尿器科学教室（主任：園田孝夫教授) \\ 瀬口 利信 岩崎 明 菅尾 英木 \\ 中野 悦次 松田稔園田 孝夫

\section{CLINICAL STATISTICS OF GERMINAL TESTICULAR CANCER} \\ Toshinobu Seguchi, Akira Iwasaki, Hideki Sugao, Etsuji Nakano, \\ Minoru Matsuda and Takao Sonoda \\ Department of Urology, Osaka University Hospital \\ (Director: Prof. T. Sonoda)
}

We experienced a hundred and fifty-six cases of germinal testicular cancer at Osaka University Hospital from 1957 to 1988.

Histologically, 114 cases $(73.1 \%)$ were simple type, and 42 cases $(26.9 \%)$ were mixed type. Eighty cases $(51.3 \%)$ were seminoma, and 76 cases $(48.7 \%)$ were non-seminoma.

All patients of seminoma were over 20 years of age, and the mean age was 36.1 years. Nonseminoma cases were distributed as to with two peaks, one in 0 to 4 year-old and another in 20 to 39 year-old, and the mean age was 22.9 years.

The seminoma/non-seminoma ratio as to clinical stages were 63 cases $/ 48$ cases in Stage 1, 6/9 in Stage 2A, 5/6 in Stage 2B and 6/13 in Stage 3.

The five-year survival rate (by Kaplan-Meier's method) was $98.4 \%$ for Stage 1 ( 71 cases), $72.7 \%$ for Stage 2A (11 cases), $0 \%$ for Stage 2B ( 4 cases) and 20\% for Stage 3 ( 5 cases) between 1957 and 1978, and $100 \%$ for Stage 1 (40 cases), Stage 2 A ( 4 cases), Stage $2 B$ ( 7 cases) and $26.8 \%$ for Stage 3 (14 cases) between 1979 and 1988.

The five-year survival rate of 20 advanced cases treated mainly by PVB regimen was $100 \%$ for Stage 2 ( 6 cases) and $68.6 \%$ for Stage 3 (14 cases). Five advanced cases containing choriocarcinoma elements were treated by PVB regimen and its two-year survival rate was $40.0 \%$, which was statistically worse than that $(86.8 \%)$ of other histological types $(p<0.05)$.

Key words: germinal testicular cancer, PVB regimen, clinical statistics

\begin{abstract}
要旨：大阪大学付属病院では1957～1988年の32年間に, 156例の胚細胞性精巣腫瘍を経験した。組織型は 114例（73.1\%）が単一組織型で42例（26.9\%）が混合組織型であり，80例（51.3\%）は seminoma, 76 例 (48.7\%) は非 seminoma であった。 seminoma は，全例20歳以上で，平均 36.1 歳であった。非 seminoma は, $0 \sim 4$ 歳, 20〜39歳の年齢帯を peak 2 峰性分布を呈し, 平均22.9歳であった. 臨床上 の病期分類は, seminoma/非 seminoma が各々, stage I：63例/48例, IIA：6 例 $/ 9$ 例, IIB $: 5$ 例/ 6 例, III $: 6$ 例/13例であった. 5 年生存率 (Kaplan-Meier 法)は, 1957 1987年で stage I(71例) $: 98.4 \%$, IIA (11例) $: 72.7 \%$, IIB ( 4 例) $: 0 \%$, III ( 5 例) $: 20 \%, 1979 \sim 1988$ 年では I (40例)・IIA（ 4 例）・ IIB ( 7 例)：100\%，III (14例)：26.8\%であった.PVB 療法を主治療として行った20例の進行癌に限れ ば， 5 年生存率は stage II（ 6 例）：100\%，III (14例)：68.6\%で，䄉毛癌の組織を含む症例では，他の 組織型の症例に較べ予後が統計上有意に（ $\mathrm{p}<0.05 ）$ 悪かった（2 年生存率で $40.0 \% / 86.8 \%)$.
\end{abstract} キーワード：胚細胞性精巣腫瘍, PVB 療法, 臨床統計 
えられる状況となった。 大阪大学泌尿器科での1974年 までの症例については，長船らが既に報告している が1), その後の治療状況の劇的な变化を考虑し, 今回 我々は1988年末むでの症例をさらに加えて臨床的検討 を行ったので報告する。

\section{対象及び方法}

1957年から1988年までの 32 年間に大阪大学泌尿器科 で加療を受けた肧細胞性精巣腫瘍154名（156例）を対 象とし, その病理組織像, 病期 (stage), 治療法, 予後 などについて検討した. なお154名中，左右の組織像の 異なる両側例 2 名を, 左右別々に検討したため, のべ 156例となった。

病理組織分類は, 辠丸腫瘍取扱規約を基本とし，便 宜的に Dixon \& Moore 分類も参考とした. 予後調査 は，病歷・アンケートを中心に行い，予後の算定は除 殬術施行日を原則的に起点としたが，生検もしくは死 後剖検等で診断確定した症例については，生検を含め た治療開始日を起点として，1989年 5 月末日までの成 績をまとめた。

\section{結 果}

1. 病理組織学的頻度：単一組織型は114例 $(73.1 \%)$ で，七ミノーマ(seminoma）が80例 (51.3\%), 胎児 性癌 (embryonal carcinoma) が16例 (10.3\%), 奇形 腫（teratoma）が13例 (8.3\%), 卵黄萇腫瘍（yolk sac tumor）が 5 例 (3.2\%) であった。一方，複合組織型 は42例(26.9\%)で, 胎児性癌との混合が40例(25.6\%), 奇形腫との混合が23例 (14.7\%), 䄉毛癌 (choriocarcinoma）との混合が13例 (8.3\%) で，絨毛癌の単独型 は無かった (Table 1).

2. 患側：片側症例は151名あり, 右76名, 左74名, 不明 1 で，左右差は認められない，両側症例は 3 名あ り, 両側セミノーマ1名, セミノーマ+奇形癌（teratocarcinoma), 胎览性癌十奇形腫が各 1 名あった。両 側セミノーマの症例は，一側から他側への転移の可能

Table 1 Histological classification

\begin{tabular}{|c|c|c|c|}
\hline Cell & type & $\begin{array}{c}\text { No. of cases } \\
\text { (\% of total cases) }\end{array}$ & Total \\
\hline \multicolumn{2}{|c|}{ Simple type: $\mathbf{s}$. } & $80(51.3 \%)$ & \\
\hline & E. & $16(10.3 \%)$ & \\
\hline & T. & $13(8.3 \%)$ & \\
\hline & Y. & $5(3.2 \%)$ & $114(73.1 \%)$ \\
\hline \multirow[t]{3}{*}{ Mixed type } & : E.+others & $40(25.6 \%)$ & \\
\hline & T.+ others & $23(14.7 \%)$ & \\
\hline & C. + others & $13(8.3 \%)$ & $42(26.9 \%)$ \\
\hline
\end{tabular}

性があるため 1 例として扱ったが，残る 2 名について は左右を別々に検討せざるを得なかったので，対象症 例は，実数154名，のべ156例となった。

3. 年齢分布：(Table 2) 便宜的に Dixon \& Moore 分類を利用し，症例をセミノーマと非セミノーマに分 けた。非セミノーマは 5 歳未満と，20，30歳台に多く 2 峰性を呈し（平均22.9歳，10歳未満の小児例を除い ても29.3歳), セミノーマは30歳台を peak に20 40歳 台に集中し, 1 峰性で(平均 36.1 歳), 全体に非セミノー マより高い年齢傾向を示した。

4. 主訴：138例（88.5\%）が陰襄内腫瘤を主訴とし て来院しこのうち有痛性が20例 (12.8\%) であった。 他に鼠径部牽引痛, 精巣部硬結が各々 6 例 (3.8\%), 2 例（1.3\%）あった。

外陰部以外の主訴は10例 (6.4\%) に見られ，下腹部 膨隆 6 例（停留精巣からの発症 1 例, 後腹膜腔巨大リ ンパ節転移 5 例), 転移巣の先行 2 例 (Virchow's meta), 無尿 1 例, 痤れん\&意識障害 1 例 (脳転移) で あった。

5. 既往歴：主な既往歴としては，停留精巣が13例 （8.3\%）にみられ，らち 4 例は固定術後の発病であっ た. 13例(24 66歳, 平均44.3歳)中, 10例がセミノー マで, 残りは絨毛癌\&セミノーマ, 胎児性癌, 奇形腫が 各 1 例あった。一方，外傷の既往はわずかに 4 例のみ で，他に副精巣炎，精巣水瘤が各 2 例あった。

6. 病期分類: Staging は日本泌尿器科学会病期分 類 ${ }^{2)}$ に従った。 その判定については, 後腹膜リンパ節廓 清術, リンパ管造影, CT 等により行ったが, 後腹膜リ ンパ節廓清術により,かつては stage IB と診断された 症例については, IIA として扱った。初診時の進展度 は，七ミノーマ/非セミノーマが各々, stage I：63例/ 48 例, IIA： 6 例 $/ 9$ 例, IIB : 5 例 $/ 6$ 例, III $: 6$ 例 $/ 13$ 例であった。

Table 2 Age \& histological distribution (by Dixon $\&$ Moore's classification)

\begin{tabular}{crrrrrr}
\multicolumn{1}{c}{ Age } & \multicolumn{1}{c}{ I } & \multicolumn{1}{c}{ II } & II & N & V & II $\sim$ V \\
\hline $0 \sim 4$ & 0 & 10 & 4 & 1 & 0 & 15 \\
$5 \sim 9$ & 0 & 0 & 2 & 0 & 0 & 2 \\
$10 \sim 14$ & 0 & 0 & 1 & 0 & 0 & 1 \\
$15 \sim 19$ & 0 & 3 & 1 & 2 & 1 & 7 \\
$20 \sim 29$ & 21 & 6 & 3 & 13 & 3 & 25 \\
$30 \sim 39$ & 34 & 8 & 2 & 7 & 3 & 20 \\
$40 \sim 49$ & 17 & 3 & 0 & 0 & 1 & 4 \\
$50 \sim 59$ & 5 & 2 & 0 & 0 & 0 & 2 \\
$60 \sim 69$ & 3 & 0 & 0 & 0 & 0 & 0 \\
\hline Total & 80 & & & & & 76
\end{tabular}


Table 3 First treatment

\begin{tabular}{|c|c|c|c|c|c|c|c|c|c|}
\hline & \multicolumn{2}{|c|}{ Seminoma } & \multicolumn{6}{|c|}{ Non-seminoma } & \multirow[b]{2}{*}{ III } \\
\hline & I & II A & II B & III & 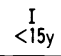 & $\begin{array}{l}\text { I } \\
\geqq 15 y\end{array}$ & II A & II B & \\
\hline 0. & 5 & & & & 15 & 10 & & & 1 \\
\hline $0 .+R$ & 58 & 6 & 2 & 4 & & 4 & 1 & & \\
\hline $0 .+5$ & & & & & & 11 & & & 1 \\
\hline O. + R. $+\mathrm{S}$ & & & & & & & 1 & & \\
\hline $0 .+C$ & & & & 2 & 3 & & & & $\overline{4}$ \\
\hline $0 .+C .+S$ & & & 3 & & & 5 & 7 & 6 & 5 \\
\hline O. + C. + R. & & & & & & & & & 2 \\
\hline
\end{tabular}

7. 治療：(Table 3) セミノーマに対しては, stage I の63例中58例と stage IIA の 6 例全例が除辠術に加 えて放射線治療を受け，残る stage I の 5 例が除辡術 のみをうけた。1985年以降の stage I は全例除睪術の みを行っている (watch and see policy). Stage IIB 以上の症例には1979年を境に，それ以前は除辠術十放 射線が，それ以後は化学療法が治療の中心となった。 な打放射線療法には，1968年以前は $\operatorname{cobalt}(\gamma$ 線)，そ れ以後は lineac ( $\beta$ 線) が行われている.

一方, 非セミノーマに対しては, 進行例では除粹術 後の化学療法が治療の中心となった. Stage III の13例 中, 2 例が化学療法を行ら機会を得㧧死亡し, 残 る症例は化学療法に加えて, 残存腫瘍があればそれに 対する廓清術か放射線療法を受けている. Stage I, II の症例に対しては，1971年以後，除辠術後の診断を兼 ねた治療として後腹膜リンパ節廓清術が原則的に行わ れ, stage Iの一部（1975年以前の若干症例）と stage II の全例に，化学療法が追加されている．ただし1985 年以後は診断的リンパ節廓清術は行わず，画像診断で stage I の症例には除辠術のみ行っている。

な扮化学療法としては, 1975年までは確定的な regimen は無く, 以後1978年まではVAB 療法が，1979年 以後は PVB 療法が第一選択として行われ，1983年以 後は再然例に対し，VP-16を含む regimen が行われて いる.

なお15歳未満の18症例は初診時の病期が全例 stage I で，簡単な予防的化学療法を受けた 3 例を除き，除辠 術のみが行われた。

8. 予後：Kaplan-Meier 法に従い, 実測生存率を計 算した. Stage 別での 5 年生存率 (以下 “ 5 生率”之略 す）は，1957 1978年の期間で， stage I (71例)： $98.4 \%$, IIA (11例) $: 72.7 \%$, IIB ( 4 例) $: 0 \%$, III
（ 5 例）：20\%，1979 1988年の最近10年間では stage I (40例) : 100\%, IIA ( 4 例) : 100\%, IIB ( 7 例): $100 \%, \operatorname{III}(14$ 例) $: 26.8 \%$ で, stage IIB で劇的な予後 の改善が認められた. しかし stage III の1979年以後の 治療成績は，CDDP の導入にも係わらず，期待をはる かに下回るものであった（Fig. 1，2）.

一方, 組織型別の 5 生率は, (1)䄉毛癌を含む type(13 例)で $52.7 \%$ ，(2)胎览性癌を含む type(50例)で $70.1 \%$, (3)奇形腫を含む type (22例) で75.7\%，であり，予後 の比較的不良な(1)との重複例を除くと，(2)・(3)は各々 (2) $\rightarrow$ (38例) $74.4 \%$ ，(3) $\rightarrow$ (17例) $81.4 \%$ であった。 更にこれを stage II 以上の進行例に限定すると(1)(2)(3) はそれぞれ（8例）：25.0\%,(18例)：46.3\%,(10例)： $64.8 \% ，$ と， 5 生率の差はさらに著明となり，䋐毛癌 を含む typeの予後不良が目だった（Fig. 3 ）。

9. 小児例：10歳末満の 17 例中 11 例までが, 2 歳末満

Fig. 1 Survival rates of 91 patients(1957 1978) (Kaplan-Meier)

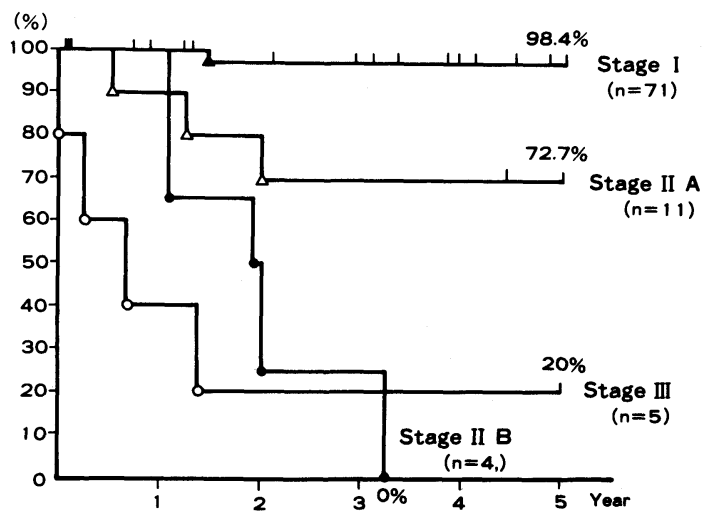

Fig. 2 Survival rates of 65 patients 1979 1988) (Kaplan-Meier)

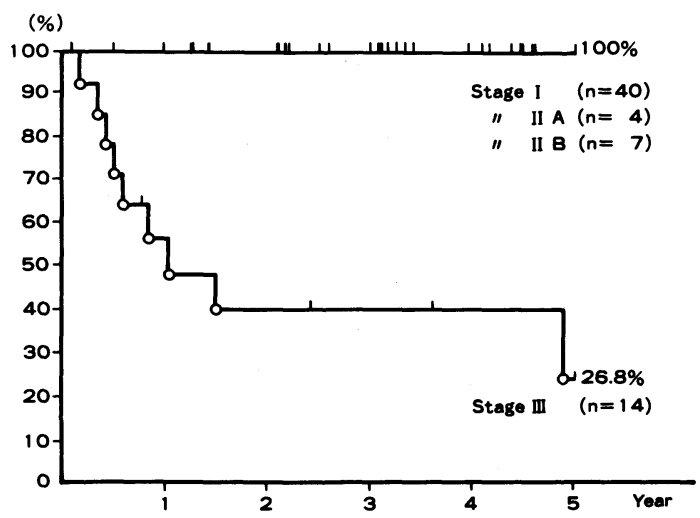


Fig. 3 Comparison of the survival rates among three histological types (choriocarcinoma, embrgonal carcinoma, teratoma) of advanced cases (stage II \& III)

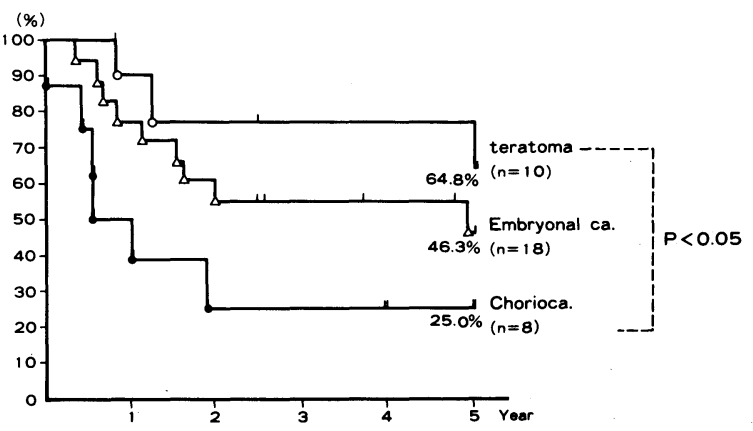

に集中している。組織型は, 胎児性癌（卵黄囊腫瘍を 含さ) 9 例, 奇形腫 6 例, 奇形癌 1 例, 卵黄囊腫瘍\&七 ミノーマ 1 例で， 4 歳以上の 3 例は全て奇形腫であっ た. 全例, stage I で, 前述のごとく原則として除鼻術 のみを行い, 胎児性癌の 1 例のみが再発死亡した。

10. CDDP (誘導体を含む) 使用例：PVB 療法を31 例に対し行った。このらち 7 例 (stage IIA：4 例, IIB : 3 例)には後腹膜リンパ節廓清術後の予防療法と して行い, 全例再発を認めていない. 残る24例（化学 療法開始時の stage は IIA：1 例, IIB：5 例, III：18 例)にはPVB療法を主治療として行った。 PVB療法 以前に他の化学療法を受けていたり, PVB療法そのも のが不完全であった 4 例（全員死亡）を除くと，のこ る20例の治療成績は, 画像診断上 CR：5 例, PR：7 例, MR：3 例, NC：3 例, PD：2 例であったが, 化 学療法後の salvage surgery の所見から PR 7 例中 4 例が病理組織学的に CR (NED) と判定された. 以上 より, CR 率は $9 / 20(45.0 \%), P R$ も含めた有効率は 12 / $20(60.0 \%)$ ) 例の計14例が再燃無く生存中で, NC 1 例が再燃加療 中である. MR, NCの非再発例 2 例は化学療法後の salvage surgery での廓清組織が成熟型奇形腫のみで あった. 20例の Kaplan-Meier 法による 5 生率は(Fig. 4), stage II ( 6 例)：100\%, stage III (14例)：68.6\% である。

\section{考察}

精巣腫瘍は本邦の報告 $\left(1980^{3)}\right)$ では人口 10 万人に対 し約 0.8 人の頻度で発生する.他の悪性腫瘍と異なる点 は, 比較的若い年齢層に多いことで, その年齢分布は, 当院の症例においても従来の報告のごとく，10歳以下
Fig. 4 Comparison of the survival rates between stage II group and stage III group treated by PVB regimen (Kaplan-Meier)

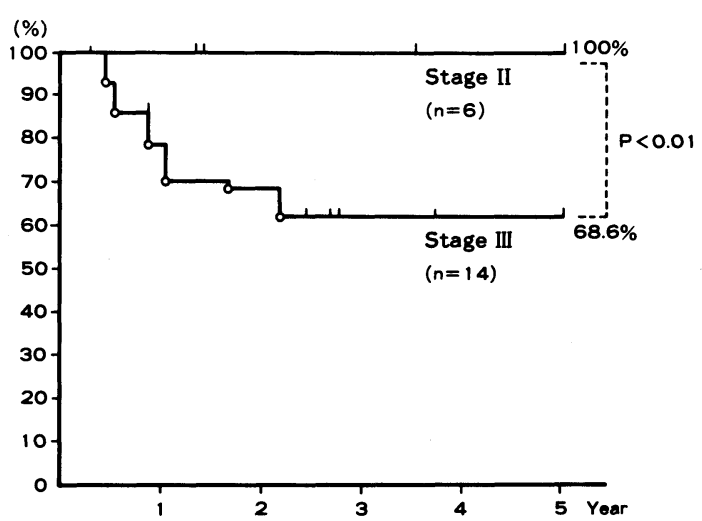

の小児（特に $2 \sim 3$ 歳迄）と20～40歳台の 2 峰性分布 を呈した。

病理組織学的には, セミノーマと非セミノーマが, いずれの報告でも各々 40 ～ $60 \%$ と半分ずつを占める が4) 8), 30歳未満では非セミノーマが, 30歳以上ではセ ミノーマが多く，特に10歳未満ではセミノーマはきわ めて稀である。

初診時の主訴 (当院) は, 当然ながら陰囊内腫瘤が 88.5\%を占め，その多くが無痛性であったが， $12.8 \%$ は有痛性であり, 副精巣炎・精巣炎など炎症疾患との 鑑別上, 合併例の可能性も含め, 十分な注意が必要と される.

治療に関しては, かつては予後も不良な疾患であっ たが，まず放射線療法の導入によって，セミノーマが 一部の進行癌を除き治癒可能となり, 続いて CDDPを 含む多剂併用療法の導入が, 非セミノーマの治療成績 をも劇的に改善し，今や完全治癒を望みうる悪性腫瘍 の 1 つになりつつある. 最近ではむしろ治療がもたら 寸副作用面に配慮し, stage I の症例（特に非セミノ一 マ）に対しては除殬術のみにとどめるといら治療方針 が採られる傾向にある (no therapy surveillance policy, watch and see plicy) ${ }^{9) \sim 11}$. 当科でも1985年以後 stage I の症例に対しては組織型にかかわらず除辠 術\&経過観察を基本方針としている。

現在, 精巣腫瘍に対する標準的化学療法として確立 されている protocolには, PVB, VAB-6があり, 進行 癌に対し, 化学療法のみで CR 率50 60\%, これに手術 療法を加える事による完全治癒率 (NED率) が 60～90\%と報告されている(12) 16). この状況の中でも， 
依然として難治性の症例群が存在しており，その危険 因子 (poor prognostic features) としては, (1) bulky metastasis (palpable retroperitoneal mass), (2)直径 $2 \mathrm{~cm}$ を越兄る肺転移, あるいは縦隔病巣, (3)肺以外の 内臟転移 (特に肝), (4)特定の組織成分 (奇形癌や䄉毛 癌?)の存在, などが考兄られている15117)18)。これら難 治症例に対しては, PVBやVAB-6が不成功に終わっ た後に, etoposide 等を含む salvage chemotherapy が 試みられているが，必ずしも満足な成績とは言えな い19).ただ既に何等かの化学療法を受けた症例では, 腫 瘍側の耐性獲得と患者の骨髄疲弊により, 完治が困難 となることは当然であり, 初期治療の成否が化学療法 では極めて重要である。それゆ克，前述の salvage chemotherapy に類する強力な protocol を治療当初 から行ら事も，一部では試みられ始めている20) 23).

な摽準的 protocol としての PVB と VAB-6の優 劣については，進行癌に対しこれまで報告されている CR 率が同程度であることそとて両者を比較する prospective な study がなされていない事などから， 結論は出せないが, VAB-6が薬剤の多様性や BLM, CDDP の特異な投与法などから見て PVB に決して劣 るものでない事は予想され，今後は前述の危険因子を 有する難治症例群に対する両者の治療成績を比較検討 する余地があると思われる。

1979年以後 (PVB 導入以後) の当科の成績では, stage II こそ 5 生率が100\%であるものの, stage III は 依然として $26.8 \%$ と不良であった. Stage III に対する PVB 療法の 5 生率が $68.6 \%$ であったことから, (1)末期 状態で治療を行えなかったり(1 例), (2)治療の中断を 繰り返したり ( 1 例), (3)他の化学療法を既に受けてい たり（3 例）した症例を含んでいることが，1979年以 後の stage III の 5 生率を悪化させている事は否め無 いが, 本邦の他施設の報告でも多くは, 欧米での進行 癌の治療成績をかなり下回る傾向が見受けられ る6) 8). そこで治療成績を悪化させているより大きな 要因として検討せねばならないのは，(1)投与 schedule の厳格性, (2)対象症例の人種格差（?）であろ5。ま ず(1)問題では, 日本人の制癌剂に対する脆弱性への 配慮から, 欧米での投薬量よりある程度の減量がしば しば行われていることが，治療成績を悪化させている 可能性は否定できない。しかし自験例の stage II 以上 の症例のうちに前述の難治症例に該当する例（bulky lesion の基準としては $\phi 10 \mathrm{~cm}$ をめどとした）が意外 に多く(65.0\%), 他の組織型に較べ予後の不良な絨毛
成分を含む症例が多い（25.0\%）ことも大きな要因で あると我々は考えており，この(2)の問題が他施設でも 認められる現象であるのかどらか, 今後の検討を期待 したい.

\section{結 語}

1. 大阪大学泌尿器科で1957年から1988年までの 32 年間に経験された156例の精巣腫崵について臨床的検 討を行った。

2. 内訳は, セミノーマ80例 (51.3\%), 非セミノー マ76例 (48.7\%) で, 病期分類ではセミノーマ/非セミ ノーマが各々, stage I：63例/48例, IIA：6 例/ 9 例, IIB : 5 例/ 6 例, III : 6 例/13例であった.

3. Kaplan-meier 法に基づく 5 年生存率は, CDDP 導入以前の1978年迄と1979年以後で, stage I : $98.4 \%$ $\rightarrow 100 \%$, IIA : $72.7 \% \rightarrow 100 \%$, IIB : $0 \% \rightarrow 100 \%$, III : $20.0 \% \rightarrow 26.8 \%$, 特に stage IIB での予後の改 善が著しかった。

4. PVB 療法を主治療として行った進行癌のうち評 価可能な20例では, CR 率が $45.0 \%, \mathrm{PR}$ も含めた有効 率が $60.0 \%$ で, 5 年生存率は stage II ( 6 例) で $100 \%$, stage III (14例) で68.6\%であった.

5. 䋐毛成分を含む症例では, 含まない症例に較べ予 後は悪く, 特に stage II 以上の進行癌では 5 生率が有 意に低かった $(\mathrm{p}<0.05)$.

1）長船匡男, 松田 稔, 古武敏彦：辠丸腫場 60 例の臨 床的統計と予後. 日泌尿会誌, 67, 515-525, 1976.

2) 日本泌尿器科学会・日本病理学会編：睪丸腫瘍取 扱い規約. 1st ed., p. 38-39, 金原出版, 東京, 1984.

3) The Research Group for Population Cancer Registration: Cancer Incidence in Japan, 1980. Osaka Cancer Registry, 1986.

4）吉田修（研究代表者）：1970年代の日本人殬丸 (精巣)腫湯の臨床統計。泌尿紀要, 31，337-356, 1985.

5) 瀬口利信, 坂口 洋, 梶川博司, 高田昌彦, 花井 淳：市立界病院での辠丸腫瘍の治療経験。泌尿紀 要, 32, 1267-1274, 1986.

6）松山豪泰, 山本憲男, 酒徳治三郎, 篠原陽一, 清水 功基：最近 10 年間の奠丸腫瘍87例の治療成績. 西 日泌尿，48，1581-1588，1986.

7）吉田一成, 川上達央, 野村一雄, 西村清志, 吳 幹 純, 高木 裕, 入江 啓, 村山雅一, 岩村正嗣, 泉 博一, 小田島邦男, 内田豊昭, 石橋 晃, 小柴 健: 辠丸腫場の臨床統計。泌尿紀要, 33, 1396-1403, 1987. 
8）繁田正信，岩佐柌夫，瀬尾一史，相模浩二, 碓井 垔, 仁手寛巳：広島大学医学部泌尿器科における 辠丸腫瘍の臨床統計. 泌尿器外科, 2, 85-89, 1989.

9) Williams, S.D., Stablein, D.M., Einhorn, L.H., Muggia, F.M., Weiss, R.B., Donohue, J.P., Paulson, D.F., Brunner, K.W., Jacobs, E.M., Spaulding, J.T., DeWys, W.D. and Crawford, E.D. : Immediate adjuvant chemotherapy versus observation with treatment at relapse in pathological stage II testicular cancer. N. Engl. J. Med., 317, 1433-1438, 1987.

10) Pizzocaro, G., Zanoni, F., Salvioni, R., Milani, A., Piva, L. and Pilloti, S.: Difficulties of a surveillance study omitting retroperitoneal lymphadenectomy in clinical stage I nonseminomatous germ cell tumors of the testis. J. Urol., 138, 1393-1396, 1987.

11) Dunphy, C.H., Ayala, A.G., Swanson, D.A., Ro, J.Y. and Logothesis, C.: Clinical stage. I. Nonseminomatous and mixed germ cell tumors of the testis. Cancer, 62, 1202-1206, 1988.

12) Einhorn, L.H.: Testicular cancer as a model for a curable neoplasm: The Richard and Hinda rosenthal foundation award lecture. Cancer Research, 41, 3275-3280, 1981.

13) Garnick, M.B., MacInture, J., Hong, W.K., Canellos, G.P. and Richie, J.P.: Advanced testicular cancer; high complete responce rate with 12 weeks of chemotherapy \pm tumor reductive surgery. Proc. Am. Soc. Clin. Oncol., 2, 142, 1983.

14) Stoter, G., Vendric, C.P.J., Struyvenberg, A., Sleyfer, D.T., Vriesendorp, R., Koops, H.S., Oosterom, A.T., Huinink, W.W.B. and Pinedo, H.M. : Five-year survival of patients with disseminated non-seminomatous testicular cancer treated with cisplatin, vinblastine and bleomycin. Cancer, 54, 1521-1524, 1984.

15）古武敏彦, 三木恒治, 松田 稔, 瀬口利信 : 辠丸腫 瘍の集学的治療。癌と化学療法, 16, 1016-1024,
1989.

16) Vugrin, D., Whitmore, W.F. Jr. and Golbey, R. B. : VAB-6 combination chemotherapy without maintenance in treatment of disseminated cancer of the testis. Cancer, 51, 211-215, 1983.

17) Javadpour, N., Ozols, R.F., Anderson, T., Barlock, A.B., Wesley, R. and Young, R.C.: A randamized trial of cytoreductive surgery followed by chemotherapy versus chemotherapy alone in bulky stage testicular cancer with poor prognostic features. Cancer, 50, 2004-2010, 1982.

18) Donohue, J.P. and Rowland, R.G.: The role of surgery in advanced testicular cancer. Cancer, 54, 2716-2721, 1984.

19) Williams, S.D. and Einhorn, L.H.: Etoposide salvage therapy for refractory germ cell tumors; an update. Cancer Treat. Rev., 9, 67-71, 1982.

20) Pizzocaro, G., Piva, L., Salvioni, R., Zanoni, F. and Milani, A.: Cisplatin, etoposide, bleomycin first-line therapy and early resection of residual tumor in far-advanced germinal testis cancer. Cancer, 56, 2411-2415, 1985.

21) Williams, S.D., Birch, R., Einhorn, L.H., Irwin, L., Greco, F.A. and Loehrer, P.J.: Treatment of disseminated germ-cell tumors with cisplatin, bleomycin and either vinblastine or etoposide. N. Eng. J. Med., 316, 1435-1440, 1987.

22) Logothesis, C.J., Samuels, M.L., Selig, D., Swanson, D., Johnson, D.E. and Eschenbach, A.C. : Improved survival with cyclic chemotherapy for nonseminomatous germ cell tumors of the testis. J. Clin. Oncol., 3, 326-335, 1985.

23) Garnick, M.B.: Advanced testicular cancer : Treatment choices in the "Land of Plenty". J. Clin. Oncol., 3, 294-297, 1985.

（1990年 3 月 14 日受理） 